\title{
The cultivation of collective judgment in the decision-making on war: the US Congress and contingently manifested war powers ${ }^{1}$
}

\author{
Anna Kronlund, The Finnish Institute of International Affairs
}

\begin{abstract}
The subject of parliamentary war powers has sparked debates of late. The role of the US Congress in making US foreign policy and in war-making has been the focus of numerous studies. Debates on the "war-making" powers of the US Congress and the President have also been topical in the United States recently. The actions of Barack Obama's administration in the context of Libya (2011), Syria (2013) and, more recently, the discussion on the need to have a new authorization for the use of force because of ISIS, have again ignited discussion about the powers of the President as the Commander-in-Chief vis-à-vis the powers of Congress. The topical question is whether and when the President should seek congressional authorization for the use of the US armed forces. This paper claims that Congress has constitutionally established war powers, but they are contingently manifested. In order to explicate this, the paper explores the procedures of congressional involvement in war-making, the term used in congressional debates in the early 1970s when the War Powers Resolution was enacted, and illustrates congressional debates on the war powers between the branches of government. The selected congressional debates on, and the procedures of, congressional actions related to the possible use of force authorizations in relation to Libya (2011) and Syria (2013) are examined more specifically to explicate the (plausible) role of Congress. In so doing, the paper draws on both political and theoretical aspects of discussions on US Congress war powers.
\end{abstract}

Keywords: US Congress, war powers, decision-making, debates, resolutions, authorizations for use of military force 


\section{Redescriptions $\quad 18 / 1$}

\section{Parliamentary war powers in praxis}

The role of parliaments in the decision-making on war, or parliamentary war powers, have recently become a point of interest (see e.g. Häkkinen 2014a, 2014b; Dieterich et al. 2008 \& 2010; Peters \& Wagner 2011 \& 2014; Tyrie 2004), as has the parliamentary oversight of foreign and security policy (see e.g. Herranz-Surrallés 2014). In their conclusion, Peters and Wagner (2011, 187) claim that "As the plethora of amendments and revisions of deployment provisions since the end of the Cold War demonstrates, war powers have remained a particularly contested issue in executive-legislative relations, both in presidential and parliamentary systems and in aligned as well as non-aligned countries". The United States is a case in point when it comes to ongoing discussions about war powers and the powers of Congress and the President in war-making.

Similar emphases have appeared elsewhere. Häkkinen (2014a, 161) writes that in Britain the House of Commons has recently become the place to discuss and decide on troop deployments due to the change in the parliamentary convention related to whether the parliament should be able to vote, and through what kind of procedure, on troop deployments. Häkkinen (ibid.) writes, "The discussion on the role of parliaments is above all a discussion on policies, but simultaneously a discussion on the constitutional positions of the legislative and the executive". The same description could be derived from the US congressional debates on war powers but the members of Congress typically also refer to the idea of collective judgment and the conception of popular sovereignty.

Comparative studies on parliaments have largely bypassed not only the matters of security and foreign policies but also the involvement of parliaments in respect of "military-security policy-making", as argued by Dieterich et al. some years ago $(2008,6)$. The US Congress has been a certain exception to this trend, however. There are numerous studies on the US Congress's foreign policy role (e.g. Johnson 2006), constitutional war powers (e.g. Zeisberg 2013), the War Powers Resolution (e.g. Grimmet 2010b; National war powers commission report 2008; Spong 1975), the Authorizations for Use of Military Force (AUMF(s)) (see e.g. Bradley and Goldsmith 2005), and the President's powers as the Commander-in-Chief (e.g. Barron \& Lederman 2008a, 2008b), to mention just a few examples. What is more, since $9 / 11$ interest has focused on the war on terror and the relations of the executive and legislature (see e.g. the special issue of the Journal of Legislative Studies in 2009 "The Impact of the 'War on Terror' on Executive-Legislative Relations: A Global Perspective"). A large number of studies on war powers and related issues are conducted by legal scholars. The studies on parliamentary war powers seem to 
have focused more on the quantitative, comparative and institutional aspects of a parliament's capabilities to be involved in the decision-making. The aim of this paper, however, is to concentrate mainly on the US Congress and the way in which the members themselves define and interpret the involvement of Congress. What is excluded from the scope of this paper is the further analysis of Congress at war, and the way in which the role of Congress has changed or been affected during the military conflicts and wars.

Tapio Raunio $(2014,545)$ has categorized the literature covering the relationship between the President and Congress with respect to foreign policy in two ways. First, there is a vast amount of literature on the competition or tension that exists between of President and Congress, in which the President is considered to have a certain (institutional) advantage in foreign policy in comparison to the domestic issues and field. This kind of research has mainly focused on the functions and doings of Congress, and in particular on roll call voting in order to examine the partisanship and positions of individuals as actors in US foreign policy. Second, researchers concentrating mainly on international economy and relations have focused on the ties between international negotiations and domestic politics (for more on the references and details, see Raunio 2014, 545). The aim here is not to consider the US foreign policy role as such, but to examine the debates (and activities) in relation to war powers in the separation of powers system. To this end, the paper draws on the actual debates in Congress on those powers that are seldom the focus of the analysis in this field from the qualitative perspective (as an exception, see e.g. Phelps \& Boylan 2002, cf. Kronlund 2013).

It has been argued that parliaments can only have a limited role in the decision-making on war. As Peters and Wagner $(2011,176)$ write, there is a certain tension between the claims of "efficiency" and "legitimacy" to use their conceptions in respect of the inclusion of parliament in the decision-making process. The US Congress has been seen as an example of a "parliament" (legislature) with considerable "war powers", particularly after it enacted the War Powers Resolution in 1973 (Dieterich et al. 2008, 6-7). As will be discussed later in this paper, the constitutionally established war powers allocated a role to Congress from the start.

The comparative aspect illustrates the differences within the legislatures in respect of their powers and procedures in the decision-making on war. An example of the differences between Congress and the British parliament in relation to the war against Iraq, particularly from the committee perspective, is provided by MP Andrew Tyrie. According to Tyrie, in the US Congress the main debates on Iraq took place in the committees, which differed from Westminster (see Tyrie 2004, 29). It should be mentioned, however, that congressional committees are considered to have a different role in the first place (see e.g. Pradshaw and Pring 1973). Nonetheless, for example, Mann and Ornstein 76 


\section{Redescriptions 18/1}

(2006) have criticized Congress's lack of oversight activities in relation to the Iraq war.

However, the role of the US Congress in decision-making on war is ambiguous in part because of the experienced controversiality of the War Powers Resolution after Congress passed the resolution in 1973 (Dieterich et al. 2008, 6-7). The resolution was seen as problematic from the moment it was considered in Congress both in terms of its substance and principles, which will be discussed in detail later in this paper. To date, the Supreme Court has not decided on the constitutionality of the resolution. Further, there are also differing opinions among constitutional lawyers concerning the congressional war powers on authority to introduce US armed forces (Dieterich et al., 2008, 6-7). What is also significantly different when compared to the parliamentary system is that in the US system both Congress and the President are accountable to the people. In the framework of the presidential system, Congress does not have similar possibilities to control the executive branch as, for example, parliaments in a cabinet government system. Congress can act, however, more independently. " $[\mathrm{As}]$ the president is not electorally dependent on the assembly ... [it] allows legislators to challenge the executive to a far greater degree than in other advanced industrial democracies, almost all of which are parliamentary systems" (Power \& Rae 2006, 5; see also Dieterich et al. 2008 \& 2010). In addition, the powers of Congress to not only legislate, but also to investigate and exert budgetary power have been conceived as superior to any other national legislative branch of government (Huntington 2005, 241).

The question that naturally arises is what is meant by war powers as such. For Peters and Wagner $(2011,178)$, parliamentary war powers are "a multidimensional concept encompassing budgetary powers, obligations of government to report to parliament or rights to visit troops during deployment". In the US context, the power of the purse is often mentioned as an effective way of controlling the executive branch, but the consultation and reporting aspects are also important, as mentioned, for example, in the War Powers Resolution. This paper, however, concentrates mainly on the debates on the authorizations of use of force in Congress and the congressional activities related to addressing the issues. ${ }^{2}$

The US Congress is in the first instance a legislature. The control over time and Congress's agenda should be stressed in this context as well. A lot more action is conducted in Congress besides voting or legislating. The public or the President can be impressed upon by ordering hearings or through letters or resolutions, or by speeches on the floor and in the media (Zoellick 2000, 34). In addition, the appropriation process and funding power are often perceived as significant ways for Congress to oversee the executive. ${ }^{3}$ For example, a resolution was passed by Congress in 1973 containing the Church-Cooper amendment to reject the use of any funds in Southeast Asia after a certain date (Zelizer 2007). 
Even though the making of US foreign policy, and conducting war in particular, are often actualized in the measures taken by the executive, there is a certain role for Congress to play that seems to be carried out in the congressional debates on the powers exerted between the branches of government. The first part of the paper maps the setting by introducing the constitutional and legislative frameworks of war powers. The subsequent part indicates Congress's war powers in the separation of powers system and the conception of the declaration of war in theory and praxis. What will be considered in particular is the constitutional interpretation of war powers and the contingent nature of these powers. In the latter part of the paper, the realm and practice of war-making is analyzed by taking a closer look at the congressional debates on war powers and the procedures of congressional activities on possible authorizations for use of military force in respect of Libya in 2011 and Syria in 2013.

This paper concentrates, through the analysis of congressional debates and congressional actions in addressing the issue in question, on the way in which the war powers of Congress and the President are detailed and defined. As will subsequently be discussed in more detail, these powers are constitutionally established, but also contingently manifested. The paper draws on both theoretical and empirical aspects of US Congress war powers and the decision-making on war in the separation of powers system. The historical point of reference concerns Congress's efforts in the early 1970s to reassert its constitutional powers by enacting the War Powers Resolution (WPR) in 1973 and the National Emergencies Act (NEA) in 1976.

Why study war powers through congressional debates? (With regard to the wider perspective of the methodological aspects of studies on parliamentary debates concerning troop deployments, see Häkkinen 2014a, 163-164.) While congressional debates are often contested from the qualitative and quantitative perspectives, the members of Congress seem to value debates as a way of maintaining the separation of powers. While there is no government opposition division in the US system, in other words no alternative is provided as such, it is possible through the debates to analyze differing conceptualizations and definitions (see Ihalainen $\&$ Palonen 2009 on the use of parliamentary debates as a corpus of research materials).

\section{Legal and political grounds for war powers debates}

As previously mentioned, there are multiple studies on US foreign policy and Congress (see e.g. Lindsay 1992; Zoellick 2000; Johnson 2006). This paper, however, aims to take a more specific and thematically limited view of congressional war powers and how they are discussed, and to examine this aspect 


\section{Redescriptions $\quad 18 / 1$}

mainly from the separation of powers system and Congress's perspective, as exemplified in the congressional debates. The debates on the presidential-congressional relations to war-making can be analyzed through three frameworks in particular: the Constitutional setting (in line with Articles I \& II), political realities and historical precedents (compare for example the "police action" in respect of the Korean War), and legislation such as the War Powers Resolution, as well as joint resolutions to authorize the use of military force (such as the AUMF of 2001 and the AUMF of 2002). The distinction is not explicit in the sense that these categories can, and often do, overlap. The Constitutional interpretation is commonly not only linked to the historical and political precedents but also to the enactment of measures such as the War Powers Resolution of 1973. The passage of this resolution meant that Congress considered the constitutionally established war powers through statutory means and set a political precedent. The implication is that the debates are continuous concerning, for example, the validity of the constitutionally granted war powers, such as the power to declare war in respect to the current political realities.

The Constitutionally shared powers define the discussion on war powers in the United States. While the powers of the President and Congress are constitutionally defined and established, the relationship between the branches of government is not immutable. The powers exerted between the branches of government are reliant on, for example, the contemporary political context, power relations within and between the executive and legislature, public opinion and the current political agenda, to mention just a few issues.

As mentioned above, the war powers of Congress and the President are defined in Articles I and II. The power of Congress to declare war is mentioned in Article I but the Constitution defines the executive branch as the Commander-in-Chief in Article II. The other topical powers of Congress are enumerated in Article I as well, including the power "to grant Letters of Marque and Reprisal, and make Rules concerning Captures on Land and Water; To raise and support Armies; To provide and maintain a Navy; To make Rules for the Government and Regulation of the land and naval Forces; To provide for calling forth the Militia to execute the Laws of the Union, suppress Insurrections and repel Invasions; and To provide for organizing, arming, and disciplining, the Militia". Furthermore, and mainly, Congress has the power to legislate (See US Constitution, Article I, sections 8 \& 1).

Because the Commander-in-Chief powers are not explicated in further detail in Article II of the Constitution, there is a certain embedded aspect of vagueness (see e.g. Barron \& Lederman 2008a, 2008b for a more detailed analysis of executive powers). In general, it has been recognized that the President has the power to respond to sudden attacks. The debates on war powers have often focused on the question of whether the President can, by unilateral decision, commit US Armed Forces to hostilities when the power to declare 
war is constitutionally granted only to Congress. As an institution, the executive has been seen as better suited to respond to situations requiring swift and decisive action (see Hamilton 1788). Former Defence Secretary Donald Rumsfeld $(2011,603)$ has acknowledged that the constitutional framework by design is the reason that Congress cannot (and should not) meet the standards of quick decision-making in exceptional situations:

By Constitutional design, Congress is intended to be slow - to promote deliberation and the weeding out of ideas that may be popular for a moment, but imprudent. Congress was not intended or organized to meet the demands of operation decision-making in a crisis. America's founding fathers knew what they were doing when they put the powers to conduct war in the hands of a single commander-inchief, not those of a committee composed of the 535 members of the national legislature.

There are three different categorizations that are usually referred to in the debates on the war powers of President and Congress: the "presidentialists" emphasize the prerogatives and "leeway" of the President; the "congressionalists" accentuate the constitutional power of Congress in respect of the declaration of war and other enumerated powers; and the "shared power" group consisting of those who argue that not only the President but also Congress has a substantial role in war-making (see Katzmann 1990, 38-39). ${ }^{4}$ Although the powers between the executive and legislature are constitutionally granted, there is some room for different interpretation. While it is clear that the Supreme Court cases can be referred to implicate the powers of the President and Congress on war-making, these are not the focus of this paper.

The possibility of amending the Constitution has been raised in order to clarify its "twilight" zone. To some extent, the issue was raised in the debates on the War Powers Resolution, but it was not seriously contemplated. There are earlier examples as well. For example, Representative Louis Ludlow (D-IN) has proposed a constitutional amendment (1938) necessitating a popular vote in advance of a declaration of war (Johnson 2006, 9).

\section{Theoretical and practical perspectives of debates on constitution- ally granted war powers}

As discussed, the Constitution establishes the formal framework between the branches of government when it comes to war-making. The question is whether and to what extent the Constitution should be read, and is read, in respect of the political realities of the time. The conception of the act of declaring war has altered considerably since it was drafted in the Constitutional Convention 


\section{Redescriptions 18/1}

in Philadelphia in 1787, not least because the practice of conducting war and the conception of war have changed over the years. The validity of the focal constitutional provision has, however, remained as exemplified in the following argument put forward by Senator Mark Dayton (D-MN) in the debate on authorization for the use of military force against Iraq in 2002: "The subsequent 204 years have demonstrated many times the wisdom and foresight of our Constitution. Its principles should give special pause to this body when being admonished by the President, by any President, not to "tie my hands". Those words indicate a regrettable lack of regard for Congress and for our constitutional standing as a coequal branch of Government. Our Nation's Founders darn well wanted to tie a President's hands" (S. J. Res. 45, Congressional Record, October 10, 2002, S10244). While the US Congress does not tend to declare war anymore, the constitutionally granted power that it can do so still frames the discussion on the role of Congress with regard to the authorizations and influences surrounding the idea that the decision to commit US armed forces to hostilities should not be made unilaterally.

It is not only the conception of declaring war that has changed but also the powers of the branches of government (see e.g. Wilson 1917, 59-60 on the changes of presidency in respect of wielding law-making power in addition to its power to execute the laws passed). In the argumentation below, Representative Mark Kirk (R-IL) traces the changes in presidential war powers and the power of Congress to declare war back to the 1950s and 1960s, and in particular to the Korean and Vietnam Wars:

With regard to military force, our founding fathers debated the proper place for the power to make war at the constitutional convention and feared it most in a new democracy. They specifically rejected proposals to give such a power to the President and directed that only the elected representatives of the American people in our Congress could declare war. For most of our history, Presidents followed the restrictions of the Constitution when going to war. In the 1950s and 1960s, we deviated from the clear requirements of the Constitution to our profound detriment $(\mathrm{H}$. J. Res. 114, Congressional Record, October 8, 2002, H7273).

As implied by the above, the debates still revolve around the constitutional clause concerning Congress's power to declare war.

Congress has not been completely bypassed by the trend for increasing the powers of the executive. It has, for example, enacted measures such as the War Powers Resolution of 1973 and the National Emergencies Act of 1976 to reassert its constitutional power. ${ }^{5}$ By enacting the War Powers Resolution, Congress aimed to reassert its constitutional responsibilities (and its institutional ones, as pointed out by Fisher 2004, 687). The debates on the resolution, however, raised many controversial questions: the Constitutional interpretation and 
reading, political realities and precedents, power relations and substance of the resolution, as well as the meaning and significance of the resolution, among other key issues. The opponents, for example, questioned the passage of the resolution right after the Vietnam War, and when the government was divided into the Democrat-controlled Congress, and the White House with a Republican president. Proponents of the resolution, however, also brought up the timing by pointing out the imbalance of powers and the support of the resolution in Congress, which was necessary because of the two-thirds majority needed to override President Nixon's veto (see Kronlund 2013 for more on the opposing and supporting arguments).

The War Powers Resolution has faced a lot of criticism since its passage. The purpose of the resolution was to restore the constitutionally envisaged "collective judgment" concerning the use of US armed forces in hostilities. The consultation and reporting requirements included in the resolution were established to secure a role for Congress in war-making. But these parts have not managed to fulfill their purpose in practice. The purpose and policy section of the joint resolution states that the Commander-in-Chief powers of the President to introduce US armed forces into hostilities should be used only in respect of the following options: when there is a declaration of war, other statutory authorization, or a national emergency. The President is expected to submit a report to Congress after introducing US armed forces into hostilities and a timeframe of 60 days for the use of armed forces is consequently set. After the 60 days (and a potential 30-day extension), the President should terminate the commitment of the use of force unless Congress declares war, provides other statutory authorization, or is unable to meet because of a national emergency (see P. L. 93-148 for details).

In practice, presidents have submitted reports consistent with the War Powers Resolution but without specifically citing the particular provision of the resolution, and have thus refrained from triggering the 60-day timeline for the commitment of the armed forces into hostilities without a congressional declaration of war or other statutory authorization. ${ }^{6}$ In addition, the question of congressional inaction with regard to either authorizing or demanding withdrawal has been considered problematic. Due to the problematic nature of the resolution, members of Congress have at regular intervals proposed amending or even repealing the resolution (a recent example will be considered in the latter part of this paper).

An interesting example of a legislative proposal concerning war powers has been the Use of Force Act by then Senator Joe Biden (D-DE) in 1995. In the Congressional findings section it is claimed that "joint deliberation by the two branches will contribute to sound decisions and to the public support necessary to sustain any use of force abroad", implying the idea of collective judgment and fulfilling the legitimacy requirement (S. 564 104th Congress March 15, 1995). ${ }^{7}$ 


\section{Redescriptions 18/1}

A recent effort to reform the War Powers Resolution was the proposal by the War Powers Commission that it should be repealed and replaced by the War Powers Consultation Act (see the National War Powers Commission Report 2008). The Peace Powers Act introduced by Senator Robert Dole (R-KS) together with a group of Senators in the 104th Congress could also be mentioned as an example of efforts to repeal to the War Powers Resolution. The Peace Powers Act of 1995 was "A Bill to clarify the war powers of Congress and the President in the post-Cold War period" (See S. 5 104th Congress). ${ }^{8}$ Proposal H.R.1111, including similar reporting requirements, was introduced in the House. What the Peace Powers Act aimed to do was overcome the idea of a legislative veto that had already been discussed when the War Powers Resolution was passed, but also to resolve the issue of possible congressional inaction (See Rotunda 1995, 6 for more on the substance of the proposals).

Because of the focus of this paper, the interesting part of the Congressional momentum of the 1970s is the reassertion of Congress's constitutional powers, particularly in relation to war and emergency powers, although the reform was not only about passing legislation. Congress also enacted some institutional and procedural changes as well as (re)considered the structures of decisionmaking aimed at enhancing the role of Congress in foreign policy decisionmaking. For example, the committee and seniority systems were revised as well as the systems by which Congress received information (Zoellick 2000; Kravitz 1990; Lindsay, 1994, 285-288).

The Constitutional framework, which is not only a system of institutions separating but also sharing powers, to use Richard Neustadt's definition (see Fisher 2005, 597), inevitably creates some tensions in the separation of power system. For example, war powers are one of the constitutionally divided powers. While there is no cabinet government style of responsibility in the US system, there are some interdependencies that should be kept in mind, for example with regard to the power relations in Congress and the White House. Zoellick $(2000,23)$ points out that the executive branch of government cannot uphold extended policies without the backing of Congress. The actual decision-making process, namely how disagreements are settled and compromises made, can appear complex and controversial. Indeed, it has been pointed out by Zoellick (ibid.) that, "Those from parliamentary systems sometimes do not recognise how America's separation of powers produces a distinctive process of governance".

The following key issues are relevant in this context: the political setting and the power relations, as well as the party dynamics in Congress, and between Congress and the White House. In times of unified government, the role of Congress as a separate branch and its oversight responsibilities have sometimes been problematized (in line with the debates after the 9/11 terrorist attacks, for example). For example, Robert Gates, the then Secretary of Defence in George 
W. Bush's administration, describes in his book Duty $(2014,50)$ how the Republican minority (and the President's party) had a specific task to restrain the Democratic majority in Congress for imposing "deadlines and timelines that would tie the president's hands" in respect to the strategy. Congress has, however, also been criticized for the "rally 'round the flag" phenomenon. During the war in Iraq, for example, it was argued that Senators from both parties were unwilling to support a nonbinding resolution (objecting the surge) that appeared to cut the troops, and the resolution did not proceed due to a lack of 60 votes to overcome the filibuster (See Senator Warner's proposal in Gates 2014, 53-54).

\section{Congressional authorizations and debates regarding uses of force}

The role of Congress in war-making often revolves around the question of the power of Congress to declare war, and whether it is valid and usable. Congress has formally declared war on 11 occasions in US history, the last instance of which was in 1942 (On declarations of war, see e.g. CRS report for Congress 2010). It has, however, authorized the President to use the armed forces (see the AUMF below), for example in 1964 in connection with the Tonkin Gulf incident, after 9/11, and in 2002 against Iraq. Congress also passed a resolution (H.J.Res. 77), namely the "Authorization for Use of Military Force Against Iraq Resolution" in 1991. Mariah Zeisberg $(2013,18)$ also refers to the fact that even though few wars have actually been declared, many of them have been authorized or supported with resolutions. What should be noted, however, is that declarations of war have different implications compared to authorizations for use of force. "With respect to domestic law, a declaration of war automatically triggers many standby statutory authorities conferring special powers on the President with respect to the military, foreign trade, transportation, communications, manufacturing, alien enemies, etc." (Elsea \& Weed 2014, summary). These statutory authorities could also be activated by a proclamation of national emergency and/or recognition that a state of war exists (ibid.).

The authorizations for the use of military force have been considered problematic for two reasons in particular. This stems firstly from the temporal aspect. Contrary to the Tonkin Gulf Resolution, which was repealed in 1971, both the 2001 and 2002 AUMFs are still valid and have been brought up in the contemporary context concerning the authority to act against ISIS (see e.g. Senate Foreign Relations committee hearing on ISIS authorization 11 March 2015). Secondly, because of the substance and wording, the resolutions are seen as problematic from both the scope and time perspectives (see Bradley $\&$ 


\section{Redescriptions $\quad 18 / 1$}

Goldsmith 2005 for AUMF 2001). In other words, the resolutions seem to be difficult to terminate, and they are possibly used more broadly than expected when enacted (see, for example, Grimmet 2010a for AUMF 2001) However, these types of resolutions are not to be taken as blank cheques as such; by authorizing or granting powers, the limitations on the available powers are also imposed by Congress (see Bradley \& Goldsmith, 2005). At least, the actions taken by the President can be weighed in the future within the framework of the authorization.

In 2013, President Obama brought up the possibility of repealing the AUMF of 2001 in a speech delivered at the National Defence University when he argued that there should be a return to normalcy in relation to war (Obama 2013). The termination of the AUMF of 2002 has also featured in recent discussions on possible authorization for the use of military force against ISIS. ${ }^{9}$ For Congress's part, there have also been different proposals to repeal both the AUMF of 2001 and the AUMF of 2002, but they have not been successful. ${ }^{10}$

Whereas Congress has the constitutionally granted power to declare war, the Constitution does not say anything about how the wars or conflicts should be terminated. ${ }^{11}$ While the authorization for the use of force can be repealed through legislative means, the means of restoring peace have also comprised a presidential proclamation or a treaty negotiated by the executive and then ratified after the Senate's advice and consent (see Elsea 2013, 15). Congress can also decide not to grant authorization for the use of force or to vote against the action taken. One relevant example is related to the US armed forces' contribution to the NATO operation in Yugoslavia in 1999. Congress voted on different motions related to the issue and it was through one of these votes that the House declined a joint resolution to authorize the war and defeated the concurrent resolution to authorize the president to conduct air strikes with NATO allies in Yugoslavia (See Silberman 2000; Garcia 2012, 8).

\section{Addressing the changing realms of war powers through statutory means}

The War Powers Resolution was passed in 1973 and was considered important at the time, but it has not worked as expected. It should be mentioned, however, that even if the resolution itself has not been regarded as a great success, the thinking behind it is still endorsed to some extent, and it continues to outline the discussions on war powers between the President and Congress. During the 113th Congress (Jan 2013-Jan 2015), Senators John McCain (RAZ) and Tim Kaine (D-VA) introduced a bill "The War Powers Consultations Act of 2014" (introduced January 16, 2014, read twice and referred to in the 
Committee on Foreign Relations) which, if passed, would have revised the 1973 WPR by reasserting the "consultative process" between the executive and legislative as to when and where US armed forces would be introduced in military action. ${ }^{12}$ Senators Kaine and McCain stressed the necessity to reform the WPR by calling it "ineffective at establishing a consultative process between the executive and legislative branches of government over our nation's most important decision - whether or not to send our men and women in uniform into harm's way" (Kaine's press release July 18, 2013).

Why have new legislation then? The provision granting Congress the power to declare war seems to be ineffectual because of the lack of actual declarations of war by Congress, but also outdated because of changes in the way in which wars are fought. As Senator McCain put it, "[t]he Constitution gives the power to declare war to Congress, but Congress has not formally declared war since June 1942, even though our nation has been involved in dozens of military actions of one scale or another since that time. There is a reason for this: The nature of war is changing. It is increasingly unlikely that the combat operations that our nation will be involved in will resemble those of rival nation-states on clearly-defined fields of battle" (Congressional Record, January 16, 2014, S441-S442).

One of the main questions after the 9/11 terrorist attacks concerned the way in which the situation and necessary authorities should be defined (compare this with the conception of the "war on terror"). Senator McCain refers to this period by arguing that, "after the September $11^{\text {th }}$ attack, we embarked on an expansive foreign policy. Spending on defense and foreign assistance went up, and energy shifted to the executive. Now, things are changing. [...] The desire to curb presidential powers across the board is growing. And the political momentum is shifting toward the Congress" (Congressional Record, January 16, 2014, S441-S442). As far back as the 1970s during the debates on the War Powers Resolution, whether and to what extent the constitutionally granted war powers were pertinent against the backdrop of the political realities of the time was a topical point of consideration. The changing nature of war calls for bringing the procedures and powers up-to-date. As a consequence, the War Powers Consultation Act of 2014 was aimed at "a new war powers consultative arrangement" between Congress and the President that would not be inconsistent with the Constitution but that would, if passed, also reflect the features of contemporary conflicts (Congressional Record, January 16, 2014, S441S442). Although the specific constitutional provision of declaring war seems to be fairly outdated in the framework of current conflicts, the argument that Congress should be involved in the decision-making on war remains valid and aspired to: "The challenge for all of us serving in the Congress is this: How do we reconcile the changing nature of war with Congress's proper role in the declaration of war? This is not exactly a new question, but it is a profound one 


\section{Redescriptions 18/1}

- for unless we in Congress are prepared to cede our constitutional authority over matters of war to the executive, we need a workable arrangement for consultation and decision-making between the executive and legislative" (Congressional Record, January 16, 2014, S441-S442). Senator McCain (ibid.) also pointed out in the course of the introduction of the Act that he sees this procedure "as the start of an important congressional and national debate, not the final word in that debate".

For Senator Kaine, the War Powers Consultation Act of 2014 would, if passed, have had two reforms compared to the War Powers Resolution of 1973. First, Congress would establish a permanent committee for consultation purposes, including both the majority and minority leaders of the Senate and the House, and the chairs and ranking members of specific committees (armed service, foreign relations, intelligence and appropriations). ${ }^{13}$ The second issue relates to the requirement to take a vote within seven days of the commitment of a military force. The vote would be about the use of force resolution drafted by the consultation committee. Akin to Senator McCain, Senator Kaine reassured members that the reason for having the resolution dealt with the changing nature of war, namely that the very concept of war has changed. The new Act would have provided an opportunity for regular consultation between the administration and Congress on the use of the armed forces in hostilities (Congressional Record, January 16, 2014, S442-S444). The consultation part was already included in the War Powers Resolution of 1973, but it has remained problematic because the resolution does not actually define the consultation in a more detailed manner, namely who should be involved in the consultation, what it should encompass, and who could feasibly evaluate whether the consultation prerequisite has been fulfilled (see the text of the resolution P.L.93148; also Ely 1988).

\section{Libya and Syria - recent examples of war powers procedures and debates in the US Congress}

The examples of congressional actions and debates in respect of Libya in 2011 and Syria in 2013 are considered here in chronological order to explicate and indicate the procedures for the decision-making on war, and for introducing US armed forces into hostilities. While the Libya case is considered more from the congressional activity perspective, the debates on the Syrian resolution in the Senate are considered in more detail to examine how the members of Congress define and explain the congressional powers, involvement, and role in the decision-making process. It should be pointed out that the debates or congressional activities have not been analyzed here from the party-affiliation perspec- 
tive per se. Discussions on partisanship and polarization have been topical in the US lately, and while there is a certain tendency towards party politics in foreign and national security policies as well, the role of the opposition seems to be somehow problematic. On the one hand, there is the "rallying 'round the flag" phenomenon, and on the other hand, the opposing or supporting party of the President (see, for example, the argument put forward by Defence Minister Robert Gates (84), who served as a defence minister in both George W. Bush's and Barack Obama's administrations).

The situation related to Libya was not seen by the administration as constituting "hostilities" in the meaning of the War Powers Resolution and hence prior congressional approval was not sought. ${ }^{14}$ According to Gates (2014, 520 ), there were differing opinions within the administration, however, on whether the President had the authority to act without congressional action. The NATO operation and the UN Security Council resolution were referred to outline legal support for the government (e.g. Fisher 2012, 176).

While no specific congressional resolution was sought by the administration, the matter still received attention in Congress. Libya is an example which illustrates the seemingly contingent and contradictory measures adopted by Congress. The resolutions are often introduced, but not always passed either to authorize or terminate (or both) the actions taken by the administration in a prior or ex post facto manner. For example, despite some supporting views (cf. S.Res.85, fn. 14), the members also opposed the unilateral action taken by the President. This was addressed in the House when a resolution was introduced (H.Con.Res.31) that would have required President Obama to seek congressional approval. The measure did not, however, proceed further than committee consideration. ${ }^{15}$ The House of Representatives, however, passed a resolution (H.Res. 292) which mentioned President Obama for not going to Congress to seek an authorization. ${ }^{16}$ Yet the House turned down a measure by Dennis Kucinich (D-OH) that would have set a time limit of 15 days for the President to withdraw from the Libya Operation. ${ }^{17}$ Some members of Congress also proceeded to challenge President Obama's actions in court. Representative Dennis Kucinich (D-OH) and nine other members of the House of Representatives filed a lawsuit against President Obama for violating the War Powers Resolution in respect of continuing the deployment of US armed forces in Libya in the absence of an authorization by Congress (Sonmez 2011). These types of efforts are not exceptional, but nor have they been successful (see Grimmet 2010b).

The question of binding or non-binding resolutions is also relevant when it comes to examples of measures considered by Congress in relation to Libya. Simple, one-house resolutions have their own meaning and purpose but they are not binding as such. This is not to say, however, that non-binding resolutions do not have any effect. In the course of the House debate on the Libya 


\section{Redescriptions 18/1}

Resolution, the format of the measures was raised, namely whether it is purposeful to have debates on non-binding resolutions. It was also pointed out that the WPR is not a "bill" and does not have the force of law as such. For example, Representative David Dreier (R-CA) stated during the House debate on the Libya Resolution that "[...] there is no such thing as the "War Powers Act'. There was a War Powers Resolution that passed that does not have the power and the strength of an enacted law" (H.Res. 292 \& H.Con.Res. 51 June 3, 2011, H3993). It seems that the "War Powers Act" is often employed when speaking about the resolution because it was the title of the Senate version of the measure as Grimmet aptly clarifies: "The law is frequently referred to as the 'War Powers Act', the title of the measure passed by the Senate. Although the latter is not technically correct, it does serve to emphasize that the War Powers Resolution, embodied in a joint resolution which complies with constitutional requirements for lawmaking, is a law" (Grimmet 2010b, 1).

The War Powers Act should not be confused, however, with the First and Second War Powers Acts of December 18, 1941 and March 27, 1942 respectively (see Rossiter 2009, 269). These delegations of power to the President by Congress were temporary and, as pointed out by Rossiter (ibid.), rather interesting because "in these statutes Congress empowered itself to revoke any of the granted powers at any time by a mere concurrent resolution". This could be compared to the similar type of provision in the War Powers Resolution, which outlined that in the event that US armed forces are introduced into hostilities without a declaration of war, the President should withdraw the forces if "the Congress so directs by concurrent resolution" (See P.L. 93-148).

Another example of the possible use of US armed forces in Syria indicated a different course of action. President Obama's administration resolved to seek congressional authorization, but in the end the vote was withdrawn when the matter was addressed through diplomatic rather than military channels. This decision has sparked debates about a possible shift in the balance of war--making) powers, or whether the decision was actually a "gambit for a political gain", to quote Douglas L. Kriner (2014). The lack of extensive international support for the actions and a UN Security Council resolution, coupled with the lack of a linkage to a direct, imminent threat to US national security, could explain the need to have congressional authorization. The possible resolution was considered in the Senate on September 9 and 10, 2013. The Syria Resolution, drafted by the Senate Foreign Relations Committee, mentioned a 60-day time limit for the authorization of the use of US armed forces (in line with the WPR language). The resolution also contained an optional 30 days if specific stipulations were observed, unless Congress enacted a prior measure specifically prohibiting the postponement of the authority. ${ }^{18}$

Senator Mitch McConnell (R-KY) defined Congress's involvement in the decision-making process, and also stressed the significance of the issue in re- 
spect of the potential use of military force in Syria, by putting it this way: "It is often said that of all the questions we face as lawmakers, none is more serious or indeed more difficult than the question of whether to commit ourselves to military action. That is why it is so important for us to have this debate, to lay out the arguments for and against military action in Syria, to let the public know where we stand on this issue and why" (Congressional Record, September 10, 2013, S6302). Senator McConnell thus emphasized the need to hear both opposing and supporting arguments, as well as the educational aspect of congressional debates.

As discussed earlier about the possible motivations for congressional authorization, similar arguments have surfaced in the Senate. The congressional vote was assumed to be particularly important because of the lack of UN and international support, as mentioned by Bernard Sanders (I-VT): [Because of unknown long-term implications and consequences] "[...] the American people are extremely concerned about the United States unilaterally going into Syria without the support of the international community and without the support of the United Nations" (Congressional Record, September 10, 2013, S6315).

The President's power to respond to sudden attacks in the US context has not really been questioned. As Senator Richard Durbin (D-IL) pointed out in his comment about presidential leadership in times of crisis: "This President could make a unilateral decision and attack without even consulting Congress and thereby maintain the element of surprise or he could do as this President has done and follow what he considers to be our constitutional requirement of a national debate before we engage in military action" (Congressional Record, September 10, 2013, S6305). The argumentation about whether the President should seek prior authorization from Congress is often connected to the differing interpretations of whether there is an imminent threat or danger to US national security, which follows that the President could act as the Commander-in-Chief (see Senator Barbara Boxer's (D-CA) argument of September 10, 2013, S6314).

With regard to the question of an imminent threat to US national security, Senator Tammy Baldwin mentioned (D-WI) that the President should indeed seek an authorization from Congress because there is no such imminent threat: "The gravity of these issues before us is significant and they deserve a full debate. President Obama should be praised for understanding and appreciating that fact. We must demand that all Presidents - not just this President - come to Congress to get approval before taking military action in another country in instances where we are not facing an imminent threat. I have made that case with both Republican and Democratic Presidents" (Congressional Record, September 10, 2013, S6319). ${ }^{19}$

It can be argued that working with Congress gives the President a certain advantage, as pointed out by Senator Tom Udall (D-NM): "The President's 


\section{Redescriptions 18/1}

mandate is stronger with congressional approval, and the mandate of the United States is stronger with international support" (Congressional Record, September 10, 2013, S6316). The day before, during the motion to proceed with the debate, Senator Daniel Coats (R-IN) also remarked that the President should have not only the support of Congress but also public support for a possible action: "We all know that taking America to war without support from the people is the surest path to disaster" (Congressional Record, September 9, 2013, S6275).

As pointed out previously by Senator McConnell, for one, an important aspect of debates in Congress is informing and educating the public. In the course of the Senate debate on the Syria Resolution, Senator Sanders raised the question of public opinion by taking up the issue of support for the use of military force: "We have a very divided Nation politically, but on this issue it appears the vast majority of Democrats, Republicans, Independents, the vast majority of progressives - I am a progressive - conservatives, moderates, have all come together to express deep concern about the United States being involved in the third military intervention in the Middle East in 12 years" (Congressional Record, September 10, 2013, S6314). The Senator's arguments contrast strongly with the rallying around the flag phenomenon.

While there were no House debates on the Syria resolution per se, the members still addressed the issue in the House. For example, Representative Peter DeFazio (D-OR) commented on the problematique of the War Powers Resolution and whether the President should actually come to Congress by saying: "Mr. Speaker, the President has come to Congress, as he should, to ask authority for a discretionary military action. The sad fact is he doesn't have to because of a defective law passed by Congress in reaction to Nixon's bombing of Cambodia in 1973. The bill that Congress passed is a shadow of our constitutional authority regarding war and peace" (Fixing the War Power Authority, September 10, 2013, H5441). In 2011, Representative DeFazio introduced "the War Powers Amendments of 2011", which was designed to "protect and defend constitutionally-supported war powers granted to Congress" (See DeFazio's press release April 6, 2011). Representative DeFazio also introduced "the War Powers Amendments of 2013" in September 2013, but it did not proceed. ${ }^{20}$

The question of war powers is also a question of checks and balances and the separation of powers. For example, by referring to the Constitution and the War Powers Resolution in relation to the authorization, Senator Benjamin Cardin (D-MD) brought up the division of power in this context as follows: "The Constitution envisions that both the President and Congress are involved in the deploying of U.S. military. Certainly the President as Commander-inChief, and the Congress, under the War Powers Act, have responsibility to authorize the use of force" (Congressional Record, September 10, 2013, S6317). In relation to the ongoing discussion on war powers it is important to note 
in the previous arguments that the members of Congress actually use different expressions to refer to the possible commitment of US armed forces and the congressional involvement in this. Senator Udall, for example, stressed in particular the definition of the authorization: "Let's be clear: This is a vote to authorize an act of war" (Congressional Record, September 10, 2013, S6316).

The actual decision-making processes have also been a focal point. Senator Harry Reid (D-NV) cited the congressional actions in relation to Syria, mentioning both the committee-level action as well as plenary session debates: "Since President Obama announced he would seek congressional approval for the limited military action against Syria, the Senate has held many committee hearings and briefings as well as five classified all-Members briefings. There are more briefings and much debate to come this week- including an open debate here in the Senate" (Congressional Record, September 9, 2013, S6274). As the aforementioned quotes concerning congressional debates - by Reid and Baldwin in particular - indicate, debating is regarded as an important part of the decision-making process. Analogously to Senator Reid, Senator Kaine, in a New York Times op-ed (2014b), commented on the fight against ISIS and remarked that, "The Constitutional involvement of Congress is not a dry constitutional principle". The Senator (ibid.) went on to talk about Congress's involvement in debating and voting, and its role in educating the public: "By debating and voting on the initiation of war, Congress educates the public about the national interests, clarifies and refines the scope of the conflict, and reinforces the core value of political consensus". Senator Kaine has emphasized Congress's need to take action because "In the current Iraq crisis, neither authorization applies" (Kaine 2014a). ${ }^{21}$

During the course of the Senate's deliberations, Senator Dan Coats (R-IN) also brought up the meaning of the resolution and the outcome for executivelegislative relations in the event that Congress would decide not to authorize the use of force:

This is a deeply historic and profound moment for our Nation. It carries an importance that goes well beyond Syria or even the Middle East. This debate carries important consequences for the relationship between the executive and legislative branches of our government. To refuse the Commander-in-Chief war-making authorities when he has asked for them is not a decision any of us can take lightly. We must all balance the views of the people we represent - even when they have been nearly unanimous - with other elements, such as the abstract, unknowable geostrategic factors that could carry profound consequences not just for this year or next year, but for many generations; and such as the compelling moral arguments that resonate with special strength in our unique Nation guided from birth by moral principles; and now even the constitutional challenges that could affect the delicate balance we have maintained for two centuries (Congressional Record, September 9, 2013, S6276). 


\section{Redescriptions 18/1}

Before President Obama announced that the administration was seeking an authorization from Congress, members of Congress brought up the need to secure authorization prior to any action. In June 2013, Representatives Tom Rooney (R-FL) and Michael McCaul (R-TX) introduced a "Congressional Accountability and Oversight in Syria Act" (H.R.2501). The proposal was assigned to a Foreign Affairs committee. If passed, the resolution would have aimed to "prohibit the President from Providing Weapons, and Military Support without Congressional Authorization"22. Selected members of Congress also sent a letter to President Obama in August 2013, which stated with reference to the Constitution and the War Powers Resolution that the President should consult and seek authorization from Congress prior to US armed forces being committed (Rigell 2013).23

Congressional support is central vis-à-vis political legitimacy for the actions of the administration in the longer perspective (Chesney et al. 2013). Certain commentators have considered the decision by President Obama to go to Congress for support for possible use of military force as a signal that congressional involvement is relevant in making US foreign policy by informal means, as pointed out by Kriner: "While much foreign policy scholarship has downplayed Congress's importance in shaping the nation's military affairs, presidential actions, such as President Obama's decision to seek congressional authorization before using force against Syria, speak to the continued influence that Congress exerts in foreign affairs through informal means" (Kriner 2014, 324).

It seems that Congress no longer formally "declares" war anymore. Presidents, however, usually benefit from going to Congress for an authorization in light of the long-term support that can be obtained from members. Kriner $(2014,312)$ writes, for example, that the decision by President Obama to seek congressional authorization on account of Syria is not meaningful because it is legally consequential, but because of the political value of these authorizations. It seems that in some respect Congress members do not change their votes even when military actions fail, do not proceed as expected, or if the expenditure is higher than envisioned (Kriner 2014). What Kriner does say, however, is that the recent example of a decision to seek congressional authorization should not be seen as a change in the realm of war powers, but rather as an act of seeking the best political option under the circumstances (Ibid. 309-311).

Adopting a quantitative approach, Kriner $(2014,318)$ has argued that the most important examples of the use of force since 1945 show that several actions taken by Congress do actually have an effect on the course of US military interventions. Measures included introducing and voting on legislative procedures to restrain the commitment of the armed forces (even if they are not passed), committee-level hearings and investigations, and commenting in public for or against the use of the armed forces (cf. Kriner 2014). Issues that could be included in the list vis-à-vis the overall influence of the US Congress are, 
for example, the appropriation process and the power of the purse, the repealing and/or amending of legislation, constitutional amendments, and institutional or procedural changes (as, for example, Lindsay 1992, 1994 has noted). Further, from the structural perspective, Congress has the power "to regulate the military, and to create the structure of the executive bureaucracy, including security-related bureaus", as mentioned by Mariah Zeisberg $(2013,6)$. In addition, many powers of the branches of government become "war powers" when they are adopted in this particular context (ibid. 50).

The measures taken, however, may be indirect rather than direct. In referring to the not so obvious aspects of congressional influence, Kriner (2014, 324-325) writes as follows: "Rather than legislatively barring the president from deploying troops abroad or cutting off funds for their continued use once deployed, members of Congress most often seek to constrain the commanderin-chief by ratcheting up the political costs of pursuing his preferred military policy course". What the members of Congress have stressed, however, is the aspect of educating the public in terms of congressional debates concerning the use of US military force.

\section{Conclusions}

The debates on the powers exercised between the branches of government in exceptional situations is one way of examining the tension between domestic and foreign policy, and studying the means by which domestic actors exert an influence on foreign policy and vice versa. The growth in the powers of the executive branch of government in foreign policy has been considered problematic vis-à-vis the constitutional principles of the separation of powers, and checks and balances. The powers have adopted different formulas, however. For example, while the US Congress has not formally declared war since 1942, it has authorized the President to use military force, for example after 9/11, and against Iraq in 2002 by passing authorizations.

The US Congress has war powers, but the question of how the position of Congress could be strengthened vis-à-vis the powers of the President remains a pertinent one. While the efficiency related to decision-making seems to favour the institutional qualities of the executive branch, the members of Congress consider debate as an important means of securing the collective judgment also when it comes to war-making.

While the theoretical framework often emphasizes certain qualities of the President and Congress in making US foreign policy, and regarding war powers in particular, the same divisions seem to appear in the congressional debates as well, often highlighted by the division of powers whereby the President is 


\section{Redescriptions $\quad 18 / 1$}

the Commander-in-Chief, and Congress has the power to declare war. What seems evident is that the shared powers should not imply bypassing Congress, but different political contexts do have an effect on how the powers of Congress and the President are (contingently) manifested.

The debates on war powers and congressional activities, for example with regard to the Libya situation in 2011, demonstrate that, despite the increase in the powers of the President, the members of Congress still consider that collective judgment should also be implemented in the decision-making on war. The purely legalistic interpretation or view of war powers is problematic because the powers are interpreted, defined and used in different political contexts. The changing characteristics of war and conflicts, and therefore the debates on the concepts and conceptions, such as war itself and the related powers, show that the debate on the involvement of Congress in the decision-making processes will likely continue. As stated by Senator John McCain during the introduction of the War Powers Consultation Act of 2014, there is a prerequisite to have a debate on the future of Congress's war powers, what is constituted by war, and consequently the potentials for Congress in the decision-making process. The introduction of the War Powers Consultation Act was seen as the start of this debate rather than the end. This paper also shows that the role of Congress in foreign policy, and particularly vis-à-vis decision-making on war, can be examined from very different perspectives other than merely through the legislative record. That said, the congressional debates (followed by votes) are considered significant by the members of Congress in securing its role in the decision-making process on the introduction of US armed forces into hostilities.

\section{Endnotes}

1 This paper builds on a paper that was originally published as a Finnish Institute of International Affairs Working Paper (no. 83) entitled "The US Congress and decision-making on war: Debates on war powers in the separation of powers system" (published 3 February 2015, see http://www.fiia.fi/f/publication/477/the_ us_congress_and_decision-making_on_war/)

2 The examples of debates analyzed here cover the Senate debate on Syria on October $9 \& 10$, 2013. The Libya references are a selected list of procedures aimed at providing examples of the debates in which the role of Congress in authorization has been stressed, rather than systematically analyzing all the debates related to multiple Libya proposals in both the House and the Senate.

3 For further details on procedural matters regarding appropriations to limit military operations, see Elsea et al. 2013; and war and appropriations in Fletcher \& Shen 2005.

4 Cf. the categorization by Phelps and Boylan (2002, 647-648): "congressionalists", 


\section{Anna Kronlund: The cultivation of collective judgment}

"presidentialists", "legalists" and "realists" in the War Powers Resolution debates.

5 Congress also passed the International Emergency Economic Powers Act (P. L. 95-223) in 1977.

6 There are numerous studies on the War Powers Resolution, its substance and meaning, related constitutional questions, and its "usability". See e.g. Grimmet 2010b; Spong 1975; Glennon 1984a, Glennon 1984b; and Fisher \& Adler 1998.

7 For the text of S.564, see https://www.congress.gov/bill/104th-congress/senatebill/564.

8 For the text of S.5, see https://www.govtrack.us/congress/bills/104/s5/text.

9 As an example, see also President Obama's letter to Congress on February 11, 2015, indicating the commitment of the President together with Congress to repeal the AUMF of 2001. The proposed resolution "To authorize the limited use of the United States Armed Forces against the Islamic State of Iraq and Levant" has a section (Sec. 6) "repeal of authorization for use of military force against Iraq". http://www.nytimes.com/interactive/2015/02/11/us/politics/document-text-ofobamas-resolution-to-authorize-military-force-against-isis.html?_r=0

10 See e.g. bipartisan bill proposal (S.1919 in 2014) by Senator Rand Paul (R-KY) (Kasperowitz 2014). Further, in May 2014, Senators Barbara Boxer (D-CA), Ben Cardin (D-MD), Robert Menendez (D-NJ), and Tim Kaine (D-VA) introduced legislation that would have repealed the 2002 AUMF Against Iraq (See Senate Foreign Relations press release May 22, 2014). Cf. similar activity in the House. In June 2014, the House Appropriations Committee voted down an amendment to the defence spending bill (FY 2015) proposed by Representative Barbara Lee, whose purpose was to ban funding for the 2002 AUMF in Iraq. The second amendment, also proposed by Lee, concerned the AUMF of 2001. http://thehill. $\mathrm{com} /$ policy/defense/208813-lawmakers-reject-official-legal-end-to-iraq-war.

11 "Exercising Congress's Constitutional Power to End a War" on January 30, 2007 by the Senate Committee on the Judiciary at http://fas.org/irp/congress/2007_hr/ endwar.pdf.

12 In line with the National War Powers Commission's proposition "the War Powers Consultation Act of 2009”. See also a proposal by Chris Gibson (R-NY) "War Powers Reform Act” on January 23, 2013. https://www.congress.gov/bill/113thcongress/house-bill/383

13 Cf. the joint congressional committee proposal by then Secretary of State William P. Rogers in the 1970s (Department of State Publications 8591, 1971, 8; Rogers 1971, 1213).

14 See White House Report on United States Activities in Libya (June 25, 2011). The Senate passed a resolution (S.Res. 85) in 2011 that "urges the United Nations Security Council to take such further action as may be necessary to protect civilians in Libya from attack, including the possible imposition of a no-fly zone over Libyan territory" http://thomas.loc.gov/cgi-bin/query/z?c112:S.RES.85.

15 See also the proposal H.Con.Res. 32 "Expressing the sense of Congress that the President should adhere to the War Powers Resolution and obtain specific statutory authorization for the use of United States Armed Forces in Libya" https:// www.congress.gov/bill/112th-congress/house-concurrent-resolution/32. For further details on the Libya resolutions in Congress and related authority, see e.g. 


\section{Redescriptions $\quad 18 / 1$}

Zeisberg, 2013; Gates, 2014.

16 See, H.Res. 292 (112th Congress) https://www.govtrack.us/congress/bills/112/ hres292/text. The resolution also set a time limit of 14 days for President Obama to explicate the strategy in Libya and to convince the members that the operation was justified and in line with the interests of the United States.

17 See H.Con.Res. 51 "Directing the President, pursuant to section 5(c) of the War Powers Resolution, to remove the United States Armed Forces from Libya". See also Fahrenthold, 2011. S.J.Res. 18 (112th Congress) "Prohibiting the deployment, establishment, or maintenance of a presence of units and members of the United States Armed Forces on the ground in Libya, and for other purposes" was also introduced in the Senate, but the Senate Committee on Foreign Relations did not report it. The Committee on Foreign Relations (United States Senate First Session, 112th Congress) held hearings on Libya and War Powers on June 28, 2011.

18 See the proposal at: http://www.foreign.senate.gov/imo/media/doc/DAV13973. pdf.

19 Senator Joe Manchin (D-WV) also introduced, together with Senator Heitkamp, S.J.Res. 22 "a joint resolution to promote a diplomatic solution in Syria, and for other purposes" to the Committee on Foreign Relations (see Congressional Record September 10, 2013, S6330).

20 See also a proposal by Representative DeFazio "War Powers Amendments Act of 1989", http://thomas.loc.gov/cgi-bin/bdquery/D?d101:21:/temp/ -bdHSnO. The proposal mentions that "“Congressional legislative authority" among the powers granted to the Congress by the Constitution includes: the power to declare war;

the power of the purse (no money shall be drawn from the Treasury, but in Consequence of Appropriations made by Law); and

the power to make all laws necessary and proper for carrying into execution not only its own powers but also all other powers vested by the Constitution in the Government of the United States, or in any department or office thereof. The proposal also contains a section on "emergency uses of the armed forces in hostilities"." The proposal was referred to the subcommittee on Rules of the House, but not considered in the House.

21 The administration's proposal was delivered to Congress in February 2015. Members of Congress have also put forward their proposals. Common to these, introduced both by the members of the House and the Senate, has been the sense of limited action, no boots on the ground, and also repealing the AUMF of 2002 (and 2001). Poplin, for example, has analyzed some of these proposals in the Lawfare blog, http://www.lawfareblog.com/2014/09/some-of-the-would-be-isisaumfs/.

22 See https://www.congress.gov/bill/113th-congress/house-bill/2501.

23 Congress confirmed the training and arming of the Syrian opposition in 2014 (House Sept. 17, 2014 and the Senate Sept. 18, 2014). The measure was regarded as an amendment to H.J.Res. 124 Continuing Appropriations Resolution 2015. See https://www.congress.gov/bill/113th-congress/house-joint-resolution/124. The support was extended in the Defence Bill for the fiscal year 2015. 
24 Congressional debates are available online 1995 onwards via Federal Digital Systems at http://www.gpo.gov/fdsys/search/home.action. For other resources to access legislative proceedings and records (substance / votes), see Thomas Library of Congress at http://thomas.loc.gov/ and Govtrack.US at https://www.govtrack. us/.

\section{Congressional debates ${ }^{24}$}

A bill to repeal the War Powers Resolution and to provide for proper war powers consultation, and for other purposes; to the Committee on Foreign Relations (S. 1939). Congressional Record (Senate), January 16, 2014, S441-442.

Authorization of the Use of United States Armed Forces Against Iraq (S.J.Res. 45). Congressional Record (Senate), October 10, 2002, S10233-S10342.

Authorizing the Limited and Specified Use of the United States Armed Forces Against Syria - Motion to Proceed (S.J.Res. 21). Congressional Record (Senate), September 9, 2013, S6273-S6284.

Authorizing the Limited and Specified Use of the United States Armed Forces Against Syria - Motion to Proceed (S.J.Res. 21). Congressional Record (Senate), September 10, 2013, S6301-S6319, S6330.

Further Consideration of H.Res. 114 Authorization for Use of Military Force Against Iraq Resolution of 2002. Congressional Record (House), October 8, 2002, H7268-H7301.

Presidential Leadership (Senator Durbin). Congressional Record (Senate), September 10, 2013, S6304-S6305.

Providing for Consideration of H.Res. 292. Regarding Deployment of United States Armed Forces in Libya, and Providing for Consideration of H.Con.Res. 51 Libya War Powers Resolution. Congressional Record (House), June 3, 2011, H3990H3998.

Regarding Deployment of United States Armed Forces in Libya. Congressional Record (House), June 3, 2011, H3998-H4021.

\section{Referenced congressional and legislative materials}

H.Con.Res. 32 Expressing the sense of Congress that the President should adhere to the War Powers Resolution and obtain specific statutory authorization for the use of United States Armed Forces in Libya. (112th Congress) https://www.congress. gov/bill/112th-congress/house-concurrent-resolution/32.

H.Con.Res. 51 Directing the President, pursuant to section 5(c) of the War Powers Resolution, to remove the United States Armed Forces from Libya. (112th Congress) http://thomas.loc.gov/cgi-bin/query/z?c112:H.CON.RES.51.

H.J.Res. 114 (P.L. 107-243) Authorization for Use of Military Force Against Iraq Resolution of 2002. (107th Congress) https://www.govtrack.us/congress/bills/107/ hjres114.

H.J.Res. 114 (P.L. 107-243) Authorization for Use of Military Force Against Iraq 


\section{Redescriptions $\quad 18 / 1$}

Resolution of 2002. (107th Congress) http://www.gpo.gov/fdsys/pkg/PLAW107publ243/html/PLAW-107publ243.htm.

H.J.Res. 542 The War Powers Resolution of 1973 (P.L.93-148). (93 $3^{\text {th }}$ Congress) US Code 50 Chapter $33 \$ 1541-\$ 1548$. http://www.law.cornell.edu/uscode/text/50/ chapter-33.

H.J.Res. 157. War Powers Amendments of 1989. (101st Congress) http://thomas.loc. gov/cgi-bin/bdquery/D?d101:21:./temp/-bdHSnO.

H.R.383 War Powers Reform Act. (113th Congress). https://www.congress.gov/ bill/113th-congress/house-bill/383.

H.R. 3884 The National Emergencies Act of 1976 (P.L.94-418). (94th Congress) US Code 50 Chapter $34 \$ 1601-\$ 1651$. http://www.law.cornell.edu/uscode/text/50/ chapter-34.

H.R. 4435 National Defense Authorization Act for Fiscal Year 2015. (113th Congress) http://thomas.loc.gov/cgi-bin/bdquery/z?d113:h.r.04435.

International Emergency Economic Powers Act (P.L.95-223). (95th Congress) http:// legcounsel.house.gov/Comps/International\%20Emergency\%20Economic\%20 Powers\%20Act.pdf.

S.5 Peace Powers Act of 1995 (104th Congress) https://www.govtrack.us/congress/ bills/104/s5.

S.564 Use of Force Act. (104th Congress) https://www.congress.gov/bill/104th-congress/senate-bill/ 564 .

S.J.Res. $18 \mathrm{~A}$ joint resolution prohibiting the deployment, establishment, or maintenance of a presence of units and members the United States Armed Forces on the ground in Libya, and for other purposes. (112th Congress) https://www.congress. gov/bill/112th-congress/senate-joint-resolution/18.

S.J.Res. 23 (P.L.107-40) Authorization for the Use of Military Force. (107th Congress) http://thomas.loc.gov/cgi-bin/bdquery/z?d107:s.j.res.00023.

S.J.Res. 23 (P.L.107-40) Authorization for the Use of Military Force. (107th Congress) https://www.govtrack.us/congress/bills/107/sjres23.

S.Res. 85 Whereas Muammar Gaddafi and his regime have engaged in gross and systematic violations of human rights, including violent attacks on protesters demanding democratic reforms. (112th Congress). http://thomas.loc.gov/cgi-bin/ query/z?c112:S.RES.85.

S.J.Res. "To authorize the limited and specified use of the United States Armed Forces against Syria". (113th Congress) Senate Committee on Foreign Relations. http:// www.foreign.senate.gov/imo/media/doc/DAV13973.pdf.

The United States Senate, Committee on Judiciary. Exercising Congress's Constitutional Power to End a War. (S. HRG. 110-902), January 30, 2007. https://fas.org/ $\mathrm{irp} /$ congress/2007_hr/endwar.pdf.

The United States Senate, Committee on Foreign Relations. The President's Request for Authorization to Use Force Against ISIS: Military and Diplomatic Efforts. March 11, 2015. http://www.foreign.senate.gov/hearings/the-presidents-request-for-authorization-to-use-force-against-isis_military-and-diplomatic-efforts-03-11-15. 
Anna Kronlund: The cultivation of collective judgment

\section{Bibliography}

BARRON, David J. and Lederman, Martin S. 2008a. The Commander in Chief at the Lowest Ebb - Framing the Problem, Doctrine, and Original Understanding. Harvard Law Review, Vol. 121, No. 3, 689-804.

BARRON, David J. and Lederman, Martin S. 2008b. The Commander in Chief at the Lowest EBB - A Constitutional History. Harvard Law Review, Vol. 121, No. 4, 941-1112.

BELASCO, Amy, et al. Congressional Restrictions on U.S. Military Operations in Vietnam, Cambodia, Laos, Somalia, and Kosovo: Funding and Non-Funding Approaches. CRS Report for Congress, January 16, 2007. https://www.hsdl.org/?search\&e xact $=$ Cunningham $\% 2 \mathrm{C}+$ Lynn $+\mathrm{J}$.\&searchfield $=$ creator\&collection=limited \&sub mitted $=$ Search \&advanced $=1$ \&creator $=$ Belasco $\% 2 C+$ Amy\&fct \&page $=1$.

BRADLEY, Curtis A. and Goldsmith, Jack L. 2005. Congressional Authorization and the War on Terrorism. Harvard Law Review, Vol. 118, No. 7, 2048-2133.

Campbell vs. Clinton, Circuit Judge Silberman. February 18, 2000. http://www.cadc. uscourts.gov/internet/opinions.nsf/1F7F789290A4B74485256F1800659772/\$f ile/99-5214a.txt.

CHESNEY, Robert, et al. 2013. A Statutory Framework for Next-Generation Terrorist Threats. Jean Perkins Task Force on National Security and Law, Congressional Research Service Library of Congress, Hoover Institution, Stanford University, 2013. http://www.hoover.org/publications/monographs/141271.

Constitution of the United States. 1787/1789. http://www.archives.gov/exhibits/charters/constitution_transcript.html.

DEFAZIO, Peter. 2011. "DeFazio defends Constitution, Introduces war powers bill”. Press release, April 6, 2011. http://defazio.house.gov/media-center/press-releases/ defazio-defends-constitution-introduces-war-powers-bill.

DIETERICH, Sandra, Hummel, Hartwig \& Marschall, Stefan. 2008. Strengthening Parliamentary 'War Powers' in Europe: Lessons from 25 National Parliaments. DCAF Policy Papers, 2008 (27), 6-7. https://www.phil-fak.uni-duesseldorf.de/ fileadmin/Redaktion/Institute/Sozialwissenschaften/Hummel_PAKS_2008.pdf.

DIETERICH, Sandra, Hummel, Hartwig \& Marschall, Stefan. 2010. Parliamentary War Powers: A Survey of 25 European Parliaments. Geneva Centre for the Democratic Control of Armed Forces. Occasional Paper No. 21.

ELSEA, Jennifer K., Garcia, Michael J., Nicola, Thomas J. 2013. Congressional Authority to Limit Military Operations. CRS Report for Congress, February 19, 2013. http://fas.org/sgp/crs/natsec/R41989.pdf.

ELSEA, Jennifer K. \& Weed, Matthew C. 2014. Declarations of War and Authorizations for the Use of Military Force: Historical Background and Legal Implications. CRS Report for Congress, April 18, 2014. http://fas.org/sgp/crs/natsec/RL31133.pdf.

ELY, John H. 1988. Suppose Congress Wanted a War Powers Act that Worked. Columbia Law Review, Vol. 88, No. 7, 1379-1431.

FAHRENTHOLD, David A. 2011. House Rebukes Obama on Libya mission, but does not demand withdrawal. The Washington Post, June 3. 2011. http://www. washingtonpost.com/politics/house-rebukes-obama-on-libya-mission-but-does- 


\section{Redescriptions $\quad 18 / 1$}

not-demand-withdrawal/2011/06/03/AGdrK8HH_story.html.

FISHER, Louis. 2012. The Law Military Operations in Libya: No War? No Hostilities? Presidential Studies Quarterly, 42, no. 1, 176-189.

FISHER, Louis. 2004. War Power. In Julian E. Zelizer (ed.), The American Congress. The Building of American Democracy. Houghton Mifflin Company, New York, 687-702.

FISHER, Louis \& Adler, David Gray. 1998. The War Powers Resolution: Time to Say Goodbye. Political Science Quarterly. Vol. 113, no. 1, 1-20.

FLETCHER, Adam \& Shen, Francis. 2005. "War and Appropriations". Harvard Law School, Federal Budget Policy Seminar. Briefing Paper, No. 9. Final Draft, May 4, 2005.

GARCIA, Michael J. 2012. War Powers Litigation Initiated by Members of Congress Since the Enactment of the War Powers Resolution. CRS Report for Congress, February 17, 2012. http://fas.org/sgp/crs/natsec/RL30352.pdf.

GATES, Robert M. 2014. Duty: Memoirs of a Secretary at War. Alfred A. Knopf, New York.

GIBSON, Chris. 2013. Gibson Introduces War Powers Reform Act to Give Americans a Voice in Decision to go to War, January 24, 2013. http://gibson.house.gov/news/ documentsingle.aspx? DocumentID $=317675$.

GLENNON, Michael J. 1984a.The War Powers Resolution Ten Years Later: More Politics than Law. The American Journal of International Law. Vol. 78, No. 3, 571-581.

GLENNON, Michael J. 1984b. The War Powers Resolution: Sad Record, Dismal Promise. Loyola of Los Angeles Law Review. Vol. 17, No. 3, 657-670.

GRIMMET, Richard F. 2010a. Instances of Use of United States Armed Forces Abroad, 1798-2009. CSR Report for Congress, January 1, 2010. http://fas.org/sgp/crs/ natsec/RL32170.pdf.

GRIMMET, Richard F. 2010b. The War Powers Resolution After Thirty-Six Years. CRS Report for Congress, April 22, 210. http://www.fas.org/sgp/crs/natsec/ R41199.pdf.

GROSS, Oren \& Aoláin Ní, Finonnuala. 2006. Law in Times of Crisis. Emergency Powers in Theory and Practice. Cambridge UP, New York.

HAMILTON, Alexander. 1788. "The Command of the Military and Naval Forces, and the Pardoning Power of the Executive". The Federalist Papers No 74. http:// thomas.loc.gov/home/histdox/fedpapers.html.

HERRANZ-SURRALLÉS, Anna. 2014. "Parliamentary oversight of EU foreign and security policy: moving beyond the patchwork?” ISPI Analysis No. 230, January 2014.

HOWELL, William G. and Pevehouse, Jon C. 2007. When Congress Stops Wars. Foreign Affairs, September/October issue, 95-107.

HUNTINGTON, Samuel P. 2005. American Ideals Versus American Institutions. In Ikenberry John G. (ed.) American Foreign Policy Theoretical Essays, $5^{\text {th }}$ edition. Houghton Mifflin Company, New York, Boston, 214-247.

HÄKKINEN, Teemu. 2014a. The concept of the Royal Prerogative in parliamentary debates on the deployment of military in the British House of Commons 19822003. Redescriptions, Vol. 17, No. 2, 160-172. 
Anna Kronlund: The cultivation of collective judgment

HÄKKINEN, Teemu. 2014b. The Royal Prerogative Redefined: Parliamentary Debate on the Role of the British Parliament in Large-scale Military Deployments, 19822003. University of Jyväskylä, Jyväskylä (dissertation).

IHALAINEN, Pasi and Palonen, Kari. 2009. Parliamentary sources in the comparative study of conceptual history: methodological aspects and illustrations of a research proposal. Parliaments, Estates, \& Representation, Vol. 29, 17-34.

JOHNSON, Robert David. 2006. Congress and the Cold War. Cambridge University Press, New York.

KAINE, Tim. 2013. "Kaine announces joint effort with McCain to reform War Powers Resolution”. July 18, 2013 (press release)http:/www.kaine.senate.gov/pressreleases/kaine-announces-joint-effort-with-mccain-to-reform-war-powers-resolution.

KAINE, Tim. 2014a."Congress has a role in U.S. military action in Iraq". Washington Post, June 24, 2014. http://www.washingtonpost.com/opinions/tim-kaine-congress-has-a-role-in-us-military-action-in-iraq/2014/06/24/77ec1776-fbc8-11e3b1f4-8e77c632c07b_story.html.

KAINE, Tim. 2014b. "Obama Must Get Congress's Backing for the Fight Against ISIS". The New York Times, September 15, 2014. http://www.nytimes.com/2014/09/16/ opinion/obama-must-get-congresss-backing-for-the-fight-against-isis.html?_r=1.

KASPEROWICZ, Pete. 2014. "Paul bill ends use military force in Iraq". The Hill, January 15, 2014. http://thehill.com/blogs/floor-action/defense/195501-paulbill-ends-use-military-force-in-iraq.

KATZMANN, Robert A. 1990. War Powers: Toward a New Accommodation. In Thomas E. Mann (ed.) A Question of Balance: The President, the Congress, and Foreign Policy. The Brookings Institution Press, Washington, 35-69.

KRAVITZ, Walter. 1990. The Advent of the Modern Congress: The Legislative Reorganization Act of 1970. Legislative Studies Quarterly, Vol. 15, No. 3. Aug. 1990, 375-399.

KRINER, Douglas L. 2014. Obama's Authorization Paradox: Syria and Congress's Continued Relevance in Military Affairs. Presidential Studies Quarterly, vol. 44, no. 2, 309-327.

KRONLUND, Anna. 2013. "Parliamentary Control of the Exceptional Situations. Debating the Reassertion of the Constitutional Powers of the US Congress." University of Jyväskylä, Jyväskylä, (dissertation).

KRONLUND, Anna. 2015. "The US Congress and the decision-making on war: Debates on war powers in the separation of powers system”. FIIA working paper (no 83). Published 3 February 2015. http://www.fiia.fi/fi/publication/477/the_ us_congress_and_decision-making_on_war/.

LINDSAY, James M. 1992. Congress and Foreign Policy: Why Hill Matters. Political Science Quarterly. Vol. 107, no. 4, 607-628.

LINDSAY, James M. 1994. Congress, Foreign Policy, and the New Institutionalism. International Studies Quarterly, Vol. 38, No. 2, 281-304.

Miller Center of Public Affairs, University of Virginia. 2008. National War Powers Commission Report. http://iis-db.stanford.edu/pubs/22193/National_War_Powers_Commission_Report.pdf.

OBAMA, Barack. 2013. "Remarks by the President at the National Defense Univer- 


\section{Redescriptions $\quad 18 / 1$}

sity”, May 23, 2013. http://www.whitehouse.gov/the-press-office/2013/05/23/remarks-president-national-defense-university.

OBAMA, Barack. 2015. "Letter to Congress". February 11, 2015. http://i2.cdn.turner.com/cnn/2015/images/02/11/2015aumf.2.11.15.msg.rel.pdf.

Obama's Resolution to Authorize Military Force Against ISIS. New York Times, February 11, 2015. http://www.nytimes.com/interactive/2015/02/11/us/politics/document-text-of-obamas-resolution-to-authorize-military-force-against-isis.html? $\mathrm{r}=0$

ORNSTEIN, Norman J. and Mann, Thomas E. 2006. When Congress Checks Out. Foreign Affairs, November/December Issue, 67-82.

OWENS, John E. Pelizzo, Ricardo. 2009. Introduction: The Impact of the 'War on Terror' on Executive-Legislative Relations: A Global Perspective. The Journal of Legislative Studies, Vol. 15, Nos. 2-3, 119-146.

PETERS, Dirk and Wagner, Wolfgang. 2011. Between Military Efficiency and Democratic Legitimacy: Mapping Parliamentary War Powers in Contemporary Democracies, 1989-2004. Parliamentary Affairs, Vol. 64, No. 1, 175-192.

PETERS, Dirk and Wagner, Wolfgang. 2014. Executive Privilege or Parliamentary Proviso? Exploringthe Sources of Parliamentary War Powers. Armed Forces \& Society, Vol. 40, No. 2, 310-331.

PHELPS, Glenn A. and Boylan, Timothy S. 2002. Discourses of War: The Landscape of Congressional Rhetoric. Armed Forces \& Society, Vol. 28, No. 4, 641-667.

POPLIN, Cody. 2014. "Four of the Would-be ISIS AUMFs". Lawfare blog. September 9, 2014. http://www.lawfareblog.com/2014/09/some-of-the-would-be-isisaumfs/.

POWER, Timothy J. and Rae, Nicol C. (eds.) 2006. Exporting Congress? The Influence of the U.S. Congress on World Legislatures. University of Pittsburgh Press, Pittsburg.

PRADSHAW, Kenneth \& Pring, David. 1973. Parliament and Congress. Quartet Books, London.

RAUNIO, Tapio. 2014. Legislatures and Foreign Policy. In Shane Martin, Thomas Saalfeld \& Kaare W. Strøm (eds), The Oxford Handbook of Legislative Studies. Oxford University Press, Oxford, 543-566.

RIGELL, Scott et al. 2013. "Letter to the President of the United States", August 28, 2013. http://rigell.house.gov/uploadedfiles/8.28.13_letter_to_potus_with_signatories.pdf.

ROGERS, William P. 1971. Principles and Pragmatism in American foreign policy. Department of State publication, 1213, 1971.

ROSSITER, Clinton. 2009 [1948]. Constitutional Dictatorship. Crisis Government in the Modern Democracies. With a new introduction by William J. Quirk. Transaction publishers, New Brunswick.

ROTUNDA, Donald R. 1995. Fixing the War Powers Act. The Heritage Lectures, The Heritage Foundation. http://www.heritage.org/research/lecture/hl529-fixing-thewar-powers-act.

RUMSFELD, Donald. 2011. Known and Unknown. A Memoir. Sentinel Penguin Books, New York.

SCHIFF, Adam. 2014. "House Narrowly Defeats Rep. Schiff Amendment Sunsetting 9/11 Authorization for Use of Military Force” (Press release), May 22, 2014. 


\section{Anna Kronlund: The cultivation of collective judgment}

http://schiff.house.gov/press-releases/house-narrowly-defeats-rep-schiff-amendment-sunsetting-911-authorization-for-use-of-military-force/.

SONMEZ, Felicia. 2011. "Kucinich, other House members file lawsuit against Obama on military mission". The Washington Post, 15 June, 2011. http://www.washingtonpost.com/blogs/2chambers/post/kucinich-other-house-members-file-lawsuit-against-obama-on-libya-military-mission/2011/06/15/AGrzd6VH_blog. html.

SPONG, William B. Jr. 1975. The War Powers Resolution Revisited: Historic Accomplishment or Surrender? William and Mary Law Review, Vol. 16, Issue 4, $823-882$.

TYRIE, Andrew. 2004. Mr. Blair's Poodle goes to War. Centre for Policy Studies. http:// www.cps.org.uk/files/reports/original/111028110720-MrBlairsPoodlegoestowar. pdf.

United States Senate Committee on Foreign Relations. 2014. "Senators Introduce Legislation to Repeal 2002 Resolution Authorizing Use of Military Force Against Iraq" (press release), May 22, 2014. http://www.foreign.senate.gov/press/chair/ release/senators-introduce-legislation-to-repeal-2002-resolution-authorizing-useof-military-force-against-iraq-.

White House. 2011. "Report on United States Activities in Libya”. June 25, 2011. https://archive.org/details/204673-united-states-activities-in-libya-6-15-11.

White House. 2014. "Notice to Congress - Terrorism". September 17, 2014. http:// www.whitehouse.gov/the-press-office/2014/09/17/notice-congress-terrorism.

WILSON, Woodrow. 1917 [1908]. Constitutional Government in the United States. Columbia University Press, New York, https://archive.org/stream/ constitutionalg00wilsgoog\#page/n70/mode/2up.

ZEISBERG, Mariah. 2013. War Powers. The Politics of Constitutional Authority. Princeton University Press, Princeton and Oxford.

ZELIZER, Julian E. 2007. How Congress Helped End the Vietnam War, The American Prospect, February 6, 2007. http://prospect.org/article/how-congress-helpedend-vietnam-war.

ZOELLICK, Robert B. 2000. Congress and the Making of US Foreign Policy. Survival, 41-4, Winter 1999-2000, 20-41. 